\title{
Oblicza liberalizmu: formowanie się krakowskiego środowiska chrześcijańskich liberałów
}

\author{
Szymon BRÓDKA*
}

\begin{abstract}
Faces of liberalism: formation of a Christian liberal community in Krakow: The aim of the essay is to show the birth of the Kraków liberal community in the years 1977-1980. An attempt is made to reconstruct the main ideological assumptions of the liberal entourage in the context of the opposition activities of Robert Kaczmarek and Mirosław Dzielski. The author refers to the main events occurring in this period, such as the establishment of the Prywatna Inicjatywa Krakowska (Private Cracow Initiative) and the magazine Merkuryusz Krakowski $i$ Światowy, as well as paying special attention to the program texts that were published in it. The article also contains a reconstruction of the debate aimed at classifying the views presented by Mirosław Dzielski.
\end{abstract}

\section{KEYWORDS}

Mirosław Dzielski; Robert Kaczmarek; Merkuryusz Krakowski i Światowy; Christian liberalism

* Asystent, Instytut Studiów Politycznych, Polska Akademia Nauk w Warszawie. E-mail: szymonbrodka@gmail.com. 
W okresie do transformacji ustrojowej polskie środowisko opozycyjne było dość zróżnicowane. Myśl liberalna docierała do wąskich kręgów społecznych, nie osiągając nigdy poziomu powszechnej świadomości. Możemy wyróżnić jedynie trzy ośrodki, w których kultywowano filozofię liberalizmu. Działały one w Krakowie, Warszawie i Gdańsku. Chronologicznie pierwszym był Kraków z drugoobiegowym periodykiem Merkuryusz Krakowski i Światowy (MKiS).

Pod koniec lat siedemdziesiątych XX wieku Robert Kaczmarek, pracownik naukowy Akademii Górniczo-Hutniczej (AGH), rozpoznawalna postać ówczesnej opozycji w Krakowie, podjął decyzję, by swoją działalność polityczną rozszerzyć o wydawanie nielegalnego czasopisma. Jak po latach wspomina, znaczny wpływ na jego decyzję miał wybór Karola Wojtyły na papieża i towarzyszący temu wydarzeniu nastrój społecznej zmiany. Pismo miało stanowić „alternatywę dla nużąco lewicowych wydawnictw KOR-u” (Koch, 2015: 39). Ostateczną decyzję podjął po zapewnieniach o wsparciu ze strony Jana Środonia (pracownika naukowego Polskiej Akademii Nauk) oraz dominikanina Jana Andrzeja Kłoczowskiego. Teksty ich autorstwa wypełniły pierwsze numery pisma (Encyklopedia Solidarności [ES], hasła: Robert Kaczmarek, Jan Środoń, Jan Andrzej Kłoczowski).

W 1978 roku Kaczmarek powołał do życia Prywatną Inicjatywę Krakowską (PIK). Jej logiem był znany z kart do gry czarny symbol pik oraz napis „Prywatna Inicjatywa Krakowska”. Za główny cel PIK przyjęła wydawanie periodyku Merkuryusz Krakowski i Światowy ${ }^{1}$ oraz wspomaganie inicjatyw z nim związanych ${ }^{2}$. Strona tytułowa Merkuryusza prócz samej nazwy miesięcznika zawierała konterfekt błazna, prawdopodobnie Stańczyka.

Periodyk jako pierwszy w Polsce miał charakter społeczno-polityczny o profilu liberalnym. Pomysłodawcą nazwy pisma był o. Jan Andrzej Kłoczowski. Zgodnie z tytułem zamierzano utrzymać pismo w stylu regionalnym, galicyjsko-krakowskim, jednocześnie podkreślając jego uniwersalny wydźwięk. Pomimo że w skład redakcji weszli wymienieni już Kaczmarek, Kłoczowski oraz Środoń, to należy uznać, że Merkuryusz przez cały okres swojej działalności był przede wszystkim inicjatywą Kaczmarka. Redakcję łączyła „Beczka” — duszpasterstwo akademickie prowadzone przy zakonie

${ }^{1} \mathrm{~W}$ artykule bazuję na numerach Merkuryusza ze zbiorów Biblioteki Jagiellońskiej. Ze względu na drugoobiegowy charakter pisma poszczególne egzemplarze mogą różnić się od siebie.

${ }^{2}$ Do najgłośniejszej z nich, a zarazem do najbardziej dochodowej, należało wydawanie śpiewników z kasetami. 
oo. dominikanów, któremu w tamtym czasie przewodniczył o. Kłoczowski (Relacja o. Jana Andrzeja Kłoczowskiego, 2018). Bywalców przyklasztornych spotkań charakteryzowało głębokie zaangażowanie w życie społeczne i polityczne kraju, dlatego też ze środowiska „Beczki” będą wywodzić się kolejni współpracownicy PIK i opozycjoniści krakowscy, tacy jak Mirosław Dzielski, Henryk Woźniakowski, Danuta Suchorowska-Sliwińska (Kłoczowski, 2015).

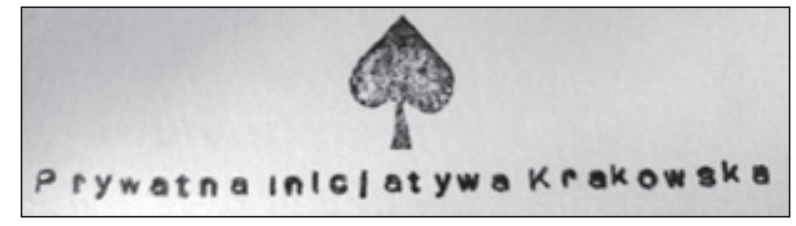

Merkuryusz w zamyśle twórcy miał być pismem „na luzie i bez bohaterszczyzny” (Koch, 2015: 40), jednocześnie jego celem było „wytworzenie programu na tu i teraz" (Koch, 2015: 40), stąd na łamach periodyku obok doniesień z Krakowa czy Watykanu pojawiały się również teksty zaangażowane ideowo, programowe lub też krytykujące rzeczywistość PRL. Rubrykę programową w pierwszych numerach wypełniały teksty Kaczmarka (pseud. Janusz Kielar), w których postulowat on stworzenie kultury politycznej, gdyż w niej widział fundament do budowania demokratycznego państwa. Według Kaczmarka sama doktryna liberalna była niewystarczająca; wymagała dodatkowej komponenty religijnej - oparcia na wartościach chrześcijańskich (Kielar, 1979a: 1-6; Lenik, 1979: 1-2).

O dystansie do siebie i postulowanym „luzie” świadczy numer 3, w którym miejsce rozważań o programie zastąpiono grafiką - co stanowiło próbę komunikacji z czytelnikami nie tylko poprzez słowa i argumenty, ale także poprzez obraz. Rysunek był prosty, lecz trafnie ujmował wizję rzeczywistości propagowaną przez pismo. Widnieją na nim dwie postacie rozmieszczone odpowiednio po lewej i po prawej stronie, skierowane frontem do leżącej między nimi cyfry. Dla jednej z nich jest to szóstka, dla drugiej — dziewiątka. Mimika bohaterów wyraźnie wskazuje na obecność sporu co do oceny sytuacji oraz, jak możemy przypuszczać, na chęć przekonania adwersarza do swoich racji.

Pierwsze trzy numery Merkuryusza wydane w 1979 roku wypełnione były, zgodnie z zapowiedzią, tekstami o wydźwięku liberalnym, zaś udział autorski Kaczmarka stanowił niemal 3/4 ich objętości. Numer 4 przyniósł przełom. Nie tylko powiększył się skład osobowy wówczas już dwumiesięcznika, lecz nowy współpracownik redakcji Mirosław Dzielski, adiunkt w Zakładzie Filozofii Nauk Przyrodniczych Instytutu Filozofii Uniwersytetu Jagiellońskiego, publikujący pod pseudonimem Adolf Romański, w znacznym stopniu przyczynił się do wyklarowania linii programowej pisma. Numer ten zawierał tekst zatytułowany Kim sq liberatowie? (Romański, 1979: 32-39). Wydany pod koniec 1979 roku 
artykuł stanowił osobisty manifest autora, w którym postulował on nowe tory myślenia społecznego oraz jako pierwszy charakteryzował krakowskich liberałów. Publikacja symbolicznie rozpoczęła karierę Dzielskiego/Romańskiego jako opozycjonisty żywo zainteresowanego problematyką społeczną, propagującego idee wolnościowe.

Artykuł Kim sq liberałowie? ukazał się w rubryce poświęconej rozważaniom nad programem Merkuryusza, co (w połączeniu z jasnym stylem tekstu) w niemal naturalny sposób uczyniło go manifestem środowiska. Publicysta określa liberałów rzecznikami wolności i rozumu, których charakteryzować ma indywidualizm i realizm. Dzielskiego wyróżnia pewna nieufność do instytucji Kościoła, którą uważa za sprzymierzoną z państwem, jednak humanizm liberałów wywodzi właśnie z chrześcijaństwa. Autor podkreśla, że wolności jednostki towarzyszy odpowiedzialność przed Bogiem. Liberalizm ma na celu ograniczenie roli państwa, którego celem jest wyłącznie ochrona wolności. Autor postuluje równość szans, ale także odpowiedzialność za swoje czyny. Liberalizm nie jest wrogiem nauki, lecz ideologii, a podział ten w marksizmie zanikł i należy go przywrócić. Liberałowie w połączeniu "gospodarczego darwinizmu z wolnościowym humanizmem widzą dźwignię ekonomicznego i społecznego postępu" (Romański, 1979: 32-39). Pod koniec swojego manifestu Dzielski określił zadania liberałów, którym przyszło żyć w „nieliberalnym i nieskorym do przyjmowania wolności społeczeństwie” (Romański, 1979: 37). Postulował swoistą pracę u podstaw, której celem jest przygotowywanie elit, a nie szybkie dążenie do władzy (której, nawet jeśliby ją zdobyli, nie byliby w stanie utrzymać). W tej długotrwałej drodze przemiany należy maksymalizować wolności obywatelskie oraz gospodarcze, nawet jeśli miałoby to oznaczać sojusze z reżimem.

Choć wolnościowe tezy członkowie redakcji i sympatycy pisma przyjmowali z aprobatą, to szczegóły, zwłaszcza dotyczące kwestii wiary czy drogi do władzy, budziły w nich nieskrywany dystans. Sam Kaczmarek w piątym numerze Merkuryusza, przy okazji publikacji erraty ${ }^{3}$ do tekstu Dzielskiego, wyraził rozczarowanie katolickiej części redakcji brakiem polemiki z zamieszczonym artykułem.

Jednoznaczne wsparcie ideowe dla Dzielskiego przyszło dopiero w następnym numerze czasopisma, gdzie opublikowano tekst Henryka Woźniakowskiego (pseud. paz) Czy liberat jest człowiekiem wolnym? (paz, 1980: 30-38). Autor na wstępie powtarza za Dzielskim deklarację, że liberałowie są miłośnikami wolności. Po czym, podnosząc kolejne wątki, rozważa niemal te same problemy, co jego poprzednik. Analizując kwestię wolności, zwraca uwagę, że grzech,

\footnotetext{
${ }^{3}$ Pomyłka w pierwodruku była olbrzymiej wagi, z tekstu wynikało bowiem, że liberałowie sami uznają się za ateistów; „Liberałowie nie zwalczają ani ateizmu, ani religii [...] Chociaż sami uważają się za ateistów”. Po poprawkach dodano: „Liberałowie nie zwalczają ani ateizmu, ani religii [...] Chociaż sami czę sto uważają się za ateistów”. Możliwe, że rozczarowanie Kaczmarka brakiem polemik wynikało po części z faktu, że nikt nie zareagował na deklarację ateizmu.
} 
zło oraz niewiedza ograniczają człowieka, niemniej dołącza do nich rozum dzięki niemu zyskujemy świadomość owego skrępowania. Autor wysuwa tezę, że człowiek poprzez poznanie swoich słabości i ograniczeń staje się bardziej wolnym. Podobnie jak Dzielski, Woźniakowski przeprowadza analizę systemów sprawowania władzy. Według niej liberalizm przeciwdziała wadom anarchii i tyranii, proponując zarazem pozytywną ewolucję w kierunku maksymalizacji wolności. Według autora liberał ,jest człowiekiem posiadającym realistyczną wizję własnej kondycji” (paz, 1980: 38).

W numerze 6 Merkuryusza ukazał się kolejny tekst Dzielskiego (sygnowany pseudonimem Adolf Romański) - Jak zachować władze w PRL. Zyczenia noworoczne Adolfa Romańskiego dla por. Jerzego Borewicza (Romański, 1980: 28-43). Nowy rok 1980 posłużył za pretekst, by zwrócić się do jednego z przedstawicieli elity $\mathrm{z}$ radą, $\mathrm{w}$ jaki sposób może on pozostać przy władzy $\mathrm{w}$ nieuchronnie zmieniającym się świecie. Adresat jest postacią fikcyjną, głównym bohaterem głośnego wówczas serialu telewizyjnego 07 zgłoś się. Niemniej grany przez Bronisława Cieślaka milicjant nosi imię Sławomir, nie zaś Jerzy. Popularność, którą cieszył się serial, oraz anegdota o tym, że autor tekstu czynif starania, by poznać osobiście odtwórcę roli Borewicza, niemal wykluczają pomyłkę (relacja Woźniakowskiego). Zaadresowanie życzeń do postaci fikcyjnej (a zarazem jej dodatkowe zanonimizowanie) było zwróceniem się do warstwy społecznej hołdującej tym samym wartościom, co wspomniany oficer Milicji Obywatelskiej. Borewicz to PRL-owski bon vivant, który według Dzielskiego utożsamia cynizm elit sprawujących władzę bez odpowiedzialności.

Symbolicznie na ręce Borewicza zatem zostaje złożona propozycja kompromisu, aby rządzący uszczuplili posiadaną władzę polityczną, wymieniając ją na tytuły własności, i zaczęli budować gospodarkę kapitalistyczną. Dzielski zatem oferował taką metodę zmian, która nie naruszałby żywotnych interesów PRL-owskich elit. Drogę tę określi później jako „twórczy antykomunizm”. Według myśliciela socjalizm nie ma przyszłości, ponieważ niszczy podstawowe zasady europejskiej cywilizacji: wydajność, sprawiedliwość i demokrację. Autor postulował poszerzenie określonych sfer wolności; chodziło o wolność produkowania, sprzedawania, podróżowania oraz ochronę prawa i swobody dla religii. Dzielski nie oczekuje, w przeciwieństwie do innych przedstawicieli opozycji, zmiany władzy politycznej, ale chce końca zakłamania, na którym opiera się socjalizm. W zamian gotów jest tolerować autorytaryzm, choć ten nie może udawać, że jest demokracją, musi wyzbyć się nowomowy. Dodawał, że obecna elita nie powinna obawiać się społecznej presji w kierunku demokratyzacji, gdyż na demokrację polskie społeczeństwo nie jest przygotowane: w istocie ludzie pragną tylko zerwać z socjalistycznym kłamstwem i socjalistycznym absurdem.

W tej koncepcji cel nadrzędny stanowiła nie demokracja, lecz wolność jednostki. Najgroźniejszy w systemie komunistycznym był brak nie demokracji, ale wolności i związanej z nią liberalnej kultury politycznej. Dla Dzielskiego mniej 
istotne było, kto rządzi, bardziej zaś, w jaki sposób sprawuje rządy oraz czy władza jest naturalnie ograniczona przez system praw, a siła nie jest nadmiernie wykorzystywana. Połączenie liberalizmu i demokracji jest stanem optymalnym, niemniej prymat należy się zawsze wolności: „Demokracja nie jest dla mnie fetyszem, nie jestem ideologiem demokracji, jestem w opozycji do tych, którzy myślą, że demokracja w Polsce rozwiąże wszystkie problemy. Sama demokracja nie wystarczy, to marzycielstwo, potrzebne są stabilizatory: warstwa średnia, ludzie odpowiedzialni, fachowcy, praca — nad demokracją trzeba się sporo napracować" (Romański, 1980: 28-43).

Po ukazaniu się kolejnego z numerów Merkuryusza kapitan Stanisław Knapik, oficer Służby Bezpieczeństwa (SB) nadzorujący Uniwersytet Jagielloński (UJ), wezwał Dzielskiego na rozpytanie. Bezpośrednim powodem spotkania były publikowane pod pseudonimem Adolf Romański teksty (między innymi manifest liberalny Merkuryusza oraz żartobliwe w tonie, ale poważne w przesłaniu życzenia do Borewicza) oraz fikcyjny wywiad z liberalnym filozofem Friedrichem A. Hayekiem, przeprowadzony jakoby przez Barbarę Jacobs (Jacobs, 1980: 25-29). Dzielski został zdekonspirowany jako ich autor. Wśród przyjaciół opowiadał anegdotę, że na zakończenie rozpytania oficer zwrócił się do niego: „Dobrze, towarzyszu, Wasze dane już mamy, a teraz dajcie adres tego Hayeka”.

Kapitan Knapik dla środowiska opozycji krakowskiej, a zwłaszcza części wywodzącej się z Uniwersytetu Jagiellońskiego, był postacią doskonale znaną. Jako główny „opiekun” uczelni z ramienia SB stał się ucieleśnieniem totalitarnego państwa wraz z jego wszelkimi wadami i absurdami ${ }^{4}$. W porównaniu do czarującego oficera Borewicza, Knapik był odarty z klasy i czaru, lecz to właśnie on dla Dzielskiego był żywym przykładem cynika, z którym można „się dogadać, oferując rozpostarcie „złotego parasola”. Zdaniem Dzielskiego zagwarantowanie takim ludziom jak on przywilejów pozwoli na powolne wyjście z komunizmu. Cynicy nie mają sentymentów do systemu, służą mu, gdyż ten zapewnia im byt (Relacja Henryka Woźniakowskiego, 2018).

Wraz z powstaniem „Solidarności” Kaczmarek zdecydował się wstrzymać działalność wydawniczą i całkowicie poświęcić ruchowi związkowemu. Jego zdaniem praca na rzecz Niezależnego Samorządnego Związku Zawodowego (NSZZ) „Solidarność”, w przeciwieństwie do kameralnego wymiaru pisma, była skuteczniejszą metodą walki o wolność (Relacja Henryka Woźniakowskiego, 2018; Koch, 2015). Były redaktor Merkuryusza rozpoczął tę nową aktywność społeczną od założenia Wolnych Związków Zawodowych oraz przewodniczenia NSZZ „Solidarność” na AGH. Następnie piastował kolejne stanowiska kierownicze, które doprowadziły go do prowadzenia Międzydzielnicowego Komitetu

\footnotetext{
${ }^{4}$ Wiele historii związanych z funkcjonariuszem SB oraz jej działalnością można odnaleźć we wspomnieniach pracowników UJ oraz aktach SB, por. Zabłocki, 2005; Kobos, 2010.
} 
„Solidarności” Krakowskiej. Dzielski zaś, mimo że nie podzielał w pełni zdania Kaczmarka i chciał dalej kontynuować działalność wydawniczą, za namową otoczenia również włączył się w ruch solidarnościowy, gdzie po krótkim czasie został małopolskim rzecznikiem prasowym związku (Koch, 2015: 41-42; ES, hasło: Robert Kaczmarek).

Historia PIK i Merkuryusza trwała przez około dwa lata, w tym czasie ukazało się dziewięć numerów, które obejmowały po 16-80 stron, a ich nakład, drukowany na powielaczu białkowym, wynosił od 300 do 800 egzemplarzy. Podsumowaniem działalności pisma był zamieszczony przez Dzielskiego nekrolog Merkuryusza: „Latem 1980 zmarł w rozkwicie sił twórczych” (por. Koch, 2015: 42; ES, hasło: Merkuryusz krakowski i światowy).

Dwaj główni autorzy Merkuryusza reprezentowali odmienne typy osobowości i zaangażowania społecznego. Pomysłodawca i założyciel pisma Robert Kaczmarek, w porównaniu z Mirosławem Dzielskim, dał się poznać jako przywódca poszukujący praktycznych rozwiązań, z konsekwencją realizujący postulat „tu i teraz". Jego teksty odnoszą się do bieżących wydarzeń, komentując zastaną rzeczywistość bez filtra cenzury. Choć w działalności Kaczmarka pojawiają się publikacje z zakresu teorii państwa, to do historii przeszła przede wszystkim jego praktyczna działalność opozycyjna.

Odmiennie jawi się postać Dzielskiego: zaangażowanie w działalność Merkuryusza pozwoliło mu połączyć prace teoretyczne (z wykształcenia był przecież filozofem) z praktyką działań opozycyjnych. Przy czym jego koncepcje polityczne usuwają nieco w cień jego działalność jako opozycjonisty i podejmowane przez niego rozmaite próby aktywizacji społeczeństwa. Z czasem Dzielski urósł do najważniejszej pod względem ideowym osoby w periodyku, a przedwczesne zamknięcie redakcji zakończyło ten etap jego kariery intelektualnej i wydawniczej. Kolejny nastąpił po stanie wojennym.

Dzielski, który aktywnie uczestniczył w pracach NSZZ „Solidarność, po grudniu 1981 roku został zaproszony do współtworzenia miesięcznika 13 grudnia. W pół roku przejął pismo, stając się jego redaktorem naczelnym i głównym ideologiem. Późniejsze założenie Krakowskiego Towarzystwa Przemysłowego (KTP) na nowo pozwoliło mu połączyć idee z czynami. W efekcie tych działań w latach osiemdziesiątych ubiegłego wieku Dzielski zasłużył na miano jednego z dwóch, obok Józefa Tischnera, ideowych przywódców krakowskiej opozycji (Koch, 2015; ES, hasło: Mirosław Dzielski; Łagowski, 2014).

Okres współpracy z Merkuryuszem miał dla Dzielskiego wymiar formacyjny. Można powiedzieć, że kształtowanie się głównych założeń ideowych myśliciela przypadło na lata 1977-19805. Czas ten wypełniają teksty drugoobiegowe ukazujące się przede wszystkim w Merkuryuszu Krakowskim i Światowym,

${ }^{5}$ Symboliczną klamrę stanowią dwie publikacje w miesięczniku Znak: Wiara Sokratesa (1977, nr 6) oraz Nauka w poszukiwaniu sensu (1980, nr 2). 
podpisywane pseudonimem Adolf Romański ${ }^{6}$. To w nich odnajdziemy główne założenia koncepcji krakowskiego myśliciela. Charakterystyczne dla pisarstwa Dzielskiego stały się postulaty wolnościowe, odnoszenie się z rezerwą do wprowadzania ustroju demokratycznego oraz idea rozumnej i ewolucyjnej, a wręcz ugodowej, drogi wyjścia z socjalizmu ku społeczeństwu kierującemu się wartościami chrześcijańskimi oraz wolnorynkową ekonomią. Idee przedstawione pod koniec lat siedemdziesiątych XX wieku zostaną konsekwentnie rozwinięte w późniejszych pracach Dzielskiego.

Jak możemy określić stanowisko Dzielskiego? Bronisław Łagowski na jednym ze spotkań seminaryjnych zaproponował filozofowi nazwę „chrześcijański liberalizm” (Łagowski, 2014). Oryginalne poglądy Dzielskiego prowokowały pytanie: czy autor czerpie więcej z tradycji liberalnej, czy konserwatywnej? Pytanie to postawili sobie nie tylko spadkobiercy i przyjaciele krakowskiego myśliciela, ale też szersze grono uczonych (Tokarczyk, 2010: 98). Spory między komentatorami dowodzą, że myśl krakowskiego działacza pozostaje atrakcyjna zarówno dla liberałów, jak i konserwatystów.

Ryszard Legutko dowodził, że Dzielski dokonał swego rodzaju anihilacji głównych postulatów liberalizmu, takich jak: dekonstrukcja ładu społecznego, porzucenie tradycji narodowo-patriotycznej czy też rozbrat z Kościołem, skutkiem czego prezentowana przez niego myśl odwołuje się do konserwatyzmu (Legutko, 1995). Z kolei Miłowit Kuniński, który w swej szczegółowej analizie dowodził zarówno liberalnych, jak i konserwatywnych proweniencji myśli Dzielskiego, ostatecznie uznał, że te ostatnie wzięły górę (Kuniński, 1994).

Głos w tej dyskusji zabrał także bliski współpracownik Dzielskiego w KTP Tadeusz Syryjczyk, który uważał, że wszelka próba rozstrzygnięcia, czy Dzielski był bardziej konserwatywny, czy liberalny, jest pozbawiona sensu, bo to właśnie połączenie tych nurtów sprawia, że jest on oryginalnym myślicielem (Syryjczyk, 2011).

Z kolei krakowski opozycjonista, profesor socjologii Kazimierz Sowa podkreśla, że Dzielski „był liberałem, ale liberałem chrześcijańskim” (Sowa, 1991: 130), o czym świadczą nie tylko jego prace teoretyczne, ale i czyny. Podobnie twierdził Jerzy Szacki, który w klasycznej już pozycji Liberalizm po komunizmie (Szacki, 1994) zakwalifikował krakowskiego myśliciela do liberałów. Szczególną uwagę zwrócił na opublikowany przez niego manifest Kim sa liberatowie?. Według badacza to symboliczny punkt, od którego zaczyna się historia współczesnego nurtu wolnościowego w Polsce. Dzielski nie tylko „wcześniej i jaśniej niż inni, sformułował szereg niekonwencjonalnych zapatrywań, lecz

${ }^{6}$ Należy tu zwrócić uwagę, że czytelnikom i opozycjonistom niewtajemniczonym w działalność wywrotową Dzielskiego nazwisko Romański było bliższe i kojarzyło się z publikacjami w Merkuryuszu. 
również [...] nazwał je liberalnymi, podejmując tym samym wysiłek usytuowania ich w szerszym kontekście ideowym i teoretycznym” (Szacki, 1994: 162).

Michael Novak trafnie stwierdził: „Ci, którzy pierwsi nazwali się liberałami, mieli na myśli trzy rodzaje instytucjonalnego wyzwolenia. Zamierzali, po pierwsze, wyzwolić ludzi od cenzury i innego ucisku sumienia, intelektu i sztuki; po drugie, uwolnić ludzi od tyranii i tortur; po trzecie, uwolnić ludzi od nędzy" (Novak, 1998: 152). W tym sensie Dzielski, jak sądzę, był liberałem najprawdziwszym.

\section{BIBLIOGRAFIA}

Dzielski, M. (1977). Wiara Sokratesa. Znak, 6, 637-647.

Dzielski, M. (1980). Nauka w poszukiwaniu sensu. Znak, 2, 135-152.

Encyklopedia Solidarności, hasła: Mirosław Dzielski; Jan Andrzej Kłoczowski; Jan Środoń; Merkuryusz krakowski i światowy; Robert Kaczmarek. Dostęp: http://www.encysol.pl/ wiki (02.2018).

Jacobs, B. [Dzielski, M.]. (1980). Rozmowa z prof. Hayekiem. Rozmawia Barbara Jacobs. Merkuryusz, 7, 25-29.

Kielar, J. [Kaczmarek, R.]. (1979a). Wokół pytania o program. Merkuryusz, 1, 1-6.

Kielar, J. [Kaczmarek, R.]. (1979b). Z narodem albo mimo narodu. Merkuryusz, 2, 12-14.

Kłoczowski, J.A. (2015). Kłocz. Autobiografia. Kraków: Wydawnictwo Literackie.

Kobos, M.A. (2010). Czasy „Solidarności” na Uniwersytecie Jagiellońskim 1980-1989. Kraków: Wydawnictwo Uniwersytetu Jagiellońskiego.

Koch, K. (2015). Pisma liberalne drugiego obiegu w Polsce w latach 1979-1990. Warszawa: Instytut Pamięci Narodowej.

Kuniński, M. (1994). Mirostaw Dzielski. Liberalizm czy konserwatyzm?. Kraków: Uniwersytet Jagielloński. [Tekst dzięki uprzejmości autora, oryginał wygłoszony na Konferencji w 25. rocznicę śmierci Mirosława Dzielskiego: „Mirosław Dzielski: Filozofia, Gospodarka, Państwo"].

Legutko, R. (1995). Konserwatyzm Dzielskiego. Kapitalista Powszechny, 10(45), 4-5.

Lenik, A. [Kaczmarek, R.]. (1979). Wokół pytania o program. Merkuryusz, 2, 1-2.

Łagowski, B. (2014). Dzielski, jakim go zapamiętałem. Kraków: Miesięcznik Społeczno-Kulturalny, 11, 12-14.

Novak, M. (1998). Wolne osoby i dobro wspólne (Przeł. G. Łuczkiewicz). Kraków: Znak.

paz [Woźniakowski, H.]. (1980). Czy liberał jest człowiekiem wolnym. Merkuryusz, 7, 30-38.

Romański, A. [Dzielski, M.]. (1979). Kim są liberałowie?. Merkuryusz, 4, 32-39.

Romański, A. [Dzielski, M.]. (1980). Jak zachować władzę w PRL. Życzenia noworoczne Adolfa Romańskiego dla por. J. Borewicza. Merkuryusz, 6, 28-43.

Sowa, K.Z. (1991). Czy Mirostaw Dzielski byt liberatem? (s. 67-73). W: B. Chrabota (Red.). Widzieć mąrość w wolności. Ksiega pamięci Mirosława Dzielskiego. Kraków: Krakowskie Towarzystwo Przemysłowe.

Syryjczyk, T. (2011). Mirosław Dzielski konserwatystą?. Liberte, 29. Dostęp: https://liberte.pl/ miroslaw-dzielski-konserwatysta (02.2018).

Szacki, J. (1994). Liberalizm po komunizmie. Kraków: Znak.

Tokarczyk, R. (2010). Wspótczesne doktryny polityczne. Warszawa: Wolters Kluwer.

Zabłocki, W. (2005). Co o nas wiedzieli? NSZZ „Solidarnośc” Uniwersytetu Jagiellońskiego w dokumentach SB. Kraków: Arcana. 
Relacje ustne zebrane przez autora:

— Relacja Jana Andrzeja Kłoczowskiego, 2018

— Relacja Henryka Woźniakowskiego, 2018

— Relacja Mariusza Szymańskiego, 2018 